\title{
ANALISIS USAHA TANI TERPADU SAPI POTONG DAN PADI SAWAH KELOMPOK TANI "KEONG MAS" KECAMATAN SANGKUB, KABUPATEN BOLAANG MONGONDOW UTARA (STUDI KASUS)
}

\author{
Judy. M. Tumewu*, V. V. J. Panelewen ${ }^{* *}$, A.D.P. Mirah ${ }^{* * *}$ \\ Fakultas Peternakan Universitas Sam Ratulangi Manado, 95115
}

\begin{abstract}
ABSTRAK
Usahatani terpadu sapi potong dan padi sawah merupakan usaha yang memadukan penggemukan sapi potong dan budidaya padi sawah yang dijalankan oleh Kelompok Tani "Keong Mas". Sapi potong dapat menyediakan kotoran sapi sebagai bahan pupuk organik dan padi sawah dapat menghasilkan jerami yang dapat dimanfaatkan sebagai pakan ternak. Perpaduan antara usaha penggemukkan sapi potong dan padi sawah diharapkan dapat menciptakan biaya produksi yang minimal dan pemanfaatan potensi sumber daya lokal. Penelitian ini dilakukan untuk mengetahui keuntungan yang diperoleh dan efisiensi biaya yang dicapai oleh kelompok tani. Metode penelitian yang digunakan adalah metode survey dengan pendekatan studi kasus. Pengumpulan data primer dilakukan dengan pengamatan langsung. Hasil penelitian menunjukkan bahwa keuntungan usahatani tunggal untuk penggemukan sapi potong sebesar Rp. 611.250 ,-/ekor/tahun. Budidaya padi sawah memberikan keuntungan sebesar Rp. $\quad 12.745 .000,-/$ hektar/tahun. Keuntungan usahatani terpadu untuk penggemukkan sapi potong, sebesar Rp. 3.477.380-/ ekor/tahun. Keuntungan budidaya padi sawah mencapai $\mathrm{Rp}$. 90.517.250,-/hektar/ tahun untuk budidaya padi sawah. Efisiensi biaya yang dicapai
\end{abstract}

*Mahasiswa PPS Unsrat

**Jurusan Sosial Ekonomi Peternakan

***Jurusan Produksi Ternak untuk penggemukkan sapi potong, sebesar Rp. 3.477.380-/ ekor/tahun. Keuntungan budidaya padi sawah mencapai Rp. 90.517.250,-/hektar/ tahun untuk budidaya padi sawah. Efisiensi biaya yang dicapai untuk usahatani terpadu, yaitu sebesar 1,49 sedangkan efisiensi biaya usaha tunggal hanya sebesar 1,16. Kesimpulannya bahwa usahatani terpadu sapi potong dan padi sawah di Kelompok Tani "Keong Mas" efisien dan menguntungkan dibanding usahatani tunggal.

Kata Kunci : usahatani terpadu, keuntungan, efisiensi biaya

ABSTRACT
ANALYSIS OF INTEGRATED
FARMING SYSTEM BETWEEN
BEEF CATTLE AND RICE PADDY
IN FARMERS GROUP OF KEONG
MAS AT SANGKUB DISTRICT,
NORTHBOLAANG MONGONDOW
REGENCY (CASE STUDY).
Integrated farming system of beef cattle
and rice paddy is a combination of beef
cattle fattening and rice paddy managed
by "Keong Mas" Farmers Group. Feces
and urine of beef cattle were materials to
produce an organic fertilizer and paddy
rice straw can be used as feed for beef
cattle. The combination of fattening beef
cattle and rice paddy straw has a
purpose to create minimum cost and
using of potential local resources. This
research purpose was to evaluate the
business profit and cost efficiency of
"Keong Mas" integrated farming
system. Research method used was
study of case and observation as the
information for collecting data. The


result showed that profit of unintegrated fattening beef cattle were $\mathrm{Rp}$. $9,780,000,-$ per 8 cattle per year. Unintegrated rice paddy gave $\mathrm{Rp}$. $12,745,000$,- profit per ha per year. The profit of integrated fattening beef cattle was Rp. 83,457,108 per 12 cattle per year and rice paddy was Rp. 90,517,250. Cost efficiency of un-integrated farming system was only 1.16 while integrated farming system gave cost efficiency of 1.49. Therefore, it can be concluded that the integrated farming system of fattening beef cattle and rice paddy in "Keong Mas" Farmers Group was profitable and efficient.

Keywords : integrated farming system, profit, cost efficiency

\section{PENDAHULUAN}

Ternak sapi sebagai salah satu komoditi peternakan merupakan sumber protein hewani yang dapat memenuhi kebutuhan nutrisi masyarakat. Budidaya ternak sapi potong sudah ada sejak dahulu hingga sekarang.Tetapi budidaya ternak sapi di desa masih dijalankan secara tradisional (Hamdan, 2011, Hoddi dkk, 2011). Pengetahuan peternak yang masih sangat terbatas menyebabkan mereka sering kesulitan dalam menjalankan usahanya. Kurangnya ketersediaan pakan di musim kemarau dengan harga yang fluktuatif menjadi kendala bagi peternak. Selain itu, modal usaha yang besar dengan waktu balik modal cukup lama merupakan pertimbangan dalam memulai usaha sapi potong. Padi sawah merupakan salah satu komoditi pertanian yang banyak dibudidayakan oleh petani di Indonesia. Permasalahannya, petani dalam proses usahataninya menggunakan produk-produk kimia untuk pemberantasan hama dan pemupukan padi sawah. Penggunaan produk-produk kimia buatan selain dapat merusak struktur tanah juga harganya relatif mahal sehingga biaya produksi yang dikeluarkan tidak sedikit.

Proses memadukan antara usaha penggemukkan sapi potong dan padi sawah merupakan salah satu solusi dalam mengatasi permasalahan petani peternak (Sariubang dkk, 2002, Suwono dkk, 2004). Pengembangan usahatani terpadu yakni dengan memanfaatkan lahan padi sebagai sumber pakan sapi dan limbah sapi sebagai bahan pupuk organic (Sudaratmadja, 2004). Perpaduan antara usaha sapi potong dan padi sawah diharapkan dapat menciptakan biaya produksi minimal dan pemanfaatan potensi sumber daya lokal. Proses usahatani padi sawah dapat dilakukan dengan 
menggunakan bahan-bahan yang tersedia di sekitar tempat usahatani tersebut tanpa mendatangkannya dari luar daerah (Ismail dan Djajanegara, 2004).

Teknologi perpaduan sapi potong dan padi sawah telah diintroduksikan oleh kelompok tani "Keong Mas" di Kecamatan Sangkub Kabupaten Bolaang Mongondow Utara. Teknologi pada usaha penggemukan sapi potong dalam bentuk pengolahan pupuk organik bersumber dari kotoran sapi . Pupuk organik ini dimanfaatkan untuk budidaya padi sawah. Pemanfaatan pupuk organic tersebut mengindikasikan bahwa biaya produksi dapat ditekan sekecil mungkin. Permasalahannya berapa besar keuntungan dan efisiensi biaya yang diperoleh kelompok tani “Keong Emas". Tujuan penelitian ini yaitu untuk menganalisis besarnya keuntungan dan efisiensi biaya usahatani terpadu sapi potong dan padi sawah yang dijalankan oleh Kelompok Tani "Keong Mas".

\section{MATERI DAN METODE PENELITIAN}

Penelitian ini dilaksanakan di kelompok tani "Keong Mas"
Kecamatan Sangkub Kabupaten Bolaang Mongondow Utara. Metode penelitian yang digunakan adalah metode survey dengan pendekatan studi kasus. Studi kasus merupakan pengkajian secara rinci terhadap sasaran penelitian dan ditelaah secara mendalam sebagai suatu totalitas sesuai dengan tujuan penelitian (Aries, 2008). Pengumpulan data digunakan dengan cara pengamatan langsung (observasi) dan memanfaatkan alat bantu berupa kuesioner. Jenis data yang digunakan dalam penelitian ini, yaitu data primer dan data sekunder. Data primer diperoleh melalui observasi dan wawancara dengan pengurus/anggota kelompok tani "Keong Mas". Data sekunder diperoleh melalui informasi dari Instansi Pemerintah dan Swasta di Kabupaten Bolaang Mongondow Utara yang terkait dengan objek penelitian. Analisis data yang digunakan adalah analisis keuntungan dan efisiensi biaya. Model analisis keuntungan sesuai dengan pendapat Malian (2004), secara matematis dapat ditulis sebagai berikut :

$$
\Pi=\text { Y.Py }-\sum^{j} \text { Xi.Pxi }- \text { BL }
$$


$\mathrm{i}=1$

Keterangan :

$\pi \quad=$ Keuntungan usahatani $(\mathrm{Rp}$

/tahun)

$\mathrm{Y}=$ Total Produksi (jumlah/tahun)

Py = Harga jual produk usahatani

$\mathrm{Xi}=$ Tingkat penggunaan input usahatani ke-i (Rp/tahun)

Pxi = Harga input usahatani ke-i

(Rp)

$\mathrm{BL}=$ Harga input ke-i $(\mathrm{Rp})$

Efisiensi biaya merupakan perbandingan antara penerimaan dan total biaya, secara matematis ditulis sebagai berikut :

$\mathrm{R} / \mathrm{C}=\mathrm{TP} / \mathrm{TB}$
Keterangan :

$\mathrm{R} / \mathrm{C}=$ Nisbah penerimaan dan biaya

NPT $=$ Nilai Total Produksi

(Rp/ tahun)

$\mathrm{TB}=$ Nilai Total Biaya

(Rp/tahun))

HASIL DAN PEMBAHASAN

$\begin{array}{rrr}\text { Hasil } & \text { penelitian biaya } \\ \text { produksi, } & \text { penerimaan dan }\end{array}$

keuntungan usaha penggemukan sapi

potong tunggal dan usaha

penggemukkan sapi terpadu dapat

dilihat pada Tabel 1.

Tabel 1. Usaha Penggemukan Sapi Potong Tunggal dan Sistem Terpadu

\begin{tabular}{|c|c|c|c|}
\hline \multirow{2}{*}{ No } & \multirow{2}{*}{ Komponen Biaya } & \multicolumn{2}{|c|}{ Nilai per Tahun (Rp) } \\
\hline & & $\begin{array}{l}\text { Usaha Penggemukan } \\
\text { Tunggal (8 ekor) }\end{array}$ & $\begin{array}{l}\text { Usaha Penggemukan } \\
\text { Terpadu (12 Ekor) }\end{array}$ \\
\hline \multirow[t]{7}{*}{1} & Biaya Produksi : & & \\
\hline & Biaya Tetap & 1.100 .000 & 9.688 .000 \\
\hline & Biaya Variabel & 111.770 .000 & 160.431 .500 \\
\hline & Biaya Pupuk Padat & & 23.922 .672 \\
\hline & Biaya Pupuk Cair & & 56.592 .000 \\
\hline & Total Biaya Produksi & 112.870 .000 & 250.634.172 \\
\hline & Biaya Produksi per Ekor & 7.054.375 & 10.443 .091 \\
\hline \multirow[t]{6}{*}{2} & Penerimaan : & & \\
\hline & Sapi Potong & 122.650 .000 & 192.000 .000 \\
\hline & Pupuk Padat & & 34.091 .280 \\
\hline & Pupuk Cair & & 108.000 .000 \\
\hline & Total Penerimaan & 122.650 .000 & 334.091 .280 \\
\hline & Penerimaan per Ekor & 7.665 .625 & 13.920 .470 \\
\hline \multirow[t]{3}{*}{3} & Keuntungan (Rp) & 9.780 .000 & 83.457.108 \\
\hline & Keuntungan per ekor $(\mathrm{Rp})$ & 611.250 & 3.477 .380 \\
\hline & Keuntungan per ekor per hari (Rp) & 3.396 & 19.319 \\
\hline
\end{tabular}

Sumber : Data Primer diolah 2014 
Data Tabel 1 menunjukkan bahwa total biaya produksi dalam usaha penggemukan terpadu lebih tinggi dibandingkan dengan penggemukkan tunggal. Penerimaan usaha penggemukkan tunggal ratarata yakni Rp. 7.665.625,-/ekor . Penerimaan pada usaha penggemukan terpadu rata-rata sebesar Rp. 13.920.470,- Besarnya penerimaan per ekor ternak dipengaruhi oleh pertambahan berat badan dan harga jual per $\mathrm{kg}$ berat hidup. Hasil penelitian biaya produksi, penerimaan dan keuntungan pada usaha budidaya padi sawah tunggal dan terpadu dapat dilihat pada Tabel 2 .

Tabel 2. Biaya Produksi, Penerimaan dan Keuntungan pada Usaha Budidaya Padi Sawah Tunggal dan Terpadu

\begin{tabular}{|c|c|c|c|}
\hline \multirow[b]{2}{*}{ No } & \multirow[b]{2}{*}{ Komponen Perhitungan } & \multicolumn{2}{|c|}{ Nilai per Tahun (Rp) } \\
\hline & & $\begin{array}{l}\text { Padi Sawah } \\
\text { Tunggal }\end{array}$ & $\begin{array}{l}\text { Padi Sawah } \\
\text { Terpadu }\end{array}$ \\
\hline \multirow[t]{15}{*}{1} & Biaya Produksi Padi Sawah & & \\
\hline & Sewa Lahan & 5.000 .000 & 5.000 .000 \\
\hline & Gudang & 3.600 .000 & 3.600 .000 \\
\hline & Kendaraan & 2.250 .000 & 2.250 .000 \\
\hline & Peralatan & 2.425 .000 & 2.425 .000 \\
\hline & Benih & 1.000 .000 & 1.000 .000 \\
\hline & Pupuk & 2.100 .000 & 1.785 .750 \\
\hline & Pembasmi Hama & 1.200 .000 & - \\
\hline & Tenaga Kerja & 19.000 .000 & 19.000 .000 \\
\hline & Bahan Bakar Minyak & 240.000 & 320.000 \\
\hline & Karung Plastik & 400.000 & 400.000 \\
\hline & Angkutan & 1.000 .000 & 1.000 .000 \\
\hline & Biaya Padi Sawah & 38.215 .000 & 36.780 .750 \\
\hline & Biaya Jerami Padi & - & 67.662 .000 \\
\hline & Total Biaya & 38.215.000 & 104.442 .750 \\
\hline \multirow[t]{3}{*}{2} & Penerimaan & & \\
\hline & Penjualan GKP & 50.960 .000 & 50.960 .000 \\
\hline & Penjualan Jerami & - & 144.000 .000 \\
\hline \multirow[t]{4}{*}{3} & Keuntungan & & \\
\hline & Keuntungan penjualan GKP & 12.745 .000 & 14.179 .250 \\
\hline & Keuntungan penjualan jerami padi & & 76.338 .000 \\
\hline & Keuntungan per ha (Rp) & 12.745.000 & 90.517 .250 \\
\hline \multicolumn{2}{|c|}{ Keuntungan per ha per hari (Rp) } & 35.403 & 251.437 \\
\hline
\end{tabular}


Budidaya padi sawah tunggal yang dijalankan oleh kelompok tani sepert pada Tabel 1 memerlukan total biaya sebesar Rp.38.215.000,/tahun. Total biaya untuk usaha terpadu sebesar Rp.104.442.750,/tahun. Hal ini disebabkan, karena usaha padi sawah terpadu menghasilkan jerami padi yang dapat dimanfaatkan sebagai pakan bagi ternak sapi. Usaha pengadaan jerami padi ini setiap tahunnya sekitar 288 ton dengan keuntungan per tahun mencapai Rp. 76.338.000,-

Biaya pupuk untuk budidaya padi sawah tunggal lebih besar dibandingkan dengan budidaya terpadu. Hal ini disebabkan oleh harga pupuk anorganik yang cukup mahal. Selain itu, budidaya padi sawah terpadu tidak lagi menggunakan pestisida dan herbisida, karena adanya penggunaan pupuk organik cair. Selain membantu pertumbuhan tanaman padi, pupuk organik cair juga berfungsi sebagai pestisida dan herbisida alami. Hasil penelitian nilai efisiensi usaha penggemukan sapi potong dan budidaya padi sawah secara tunggal dapat dilihat pada Tabel 3.
Data pada Tabel 3 menunjukkan bahwa usaha penggemukkan sapi potong terpadu lebih efisien daripada usaha tunggal. Hal ini dilihat dari biaya produksi dan penerimaan untuk usaha tunggal lebih kecil sehingga nilai $\mathrm{R} / \mathrm{C}$ yang dihasilkan pun kecil. Berbeda dengan usaha terpadu dimana biaya produksi yang tinggi diikuti oleh penerimaan yang juga cukup tinggi. Terjadi peningkatan nilai $\mathrm{R} / \mathrm{C}$ pada usaha penggemukan sapi potong terpadu sebesar 12,62\%. Peningkatan nila R/C pada budidaya padi sawah adalah sebesar $4,51 \%$. Nilai efisiensi usaha penggemukan sapi potong dan budidaya padi sawah terpadu sesuai hasil penelitian dapat dilihat pada Tabel 4.

Keuntungan dari usaha tunggal penggemukkan sapi potong dan budidaya padi sawah sesuai Tabel 4 sebesar Rp.25.109.000,- atau sebesar $16,32 \%$ dari total biaya, sedangkan keuntungan usahatani terpadu sebesar Rp.173.974.358,- $\quad$ atau mencapai $49 \%$ dari total biaya produksi. Kenaikan keuntungan bahkan mencapai lebih dari 100\% karena adanya kegiatan usaha tambahan, yakni pengolahan pupuk 
Tabel 3. Nilai Efisiensi Usaha Penggemukan Sapi Potong dan Budidaya Padi Sawah Tunggal

\section{Usaha Tunggal}

\begin{tabular}{rlrrr}
\cline { 3 - 4 } No & Komponen Biaya & $\begin{array}{c}\text { Usaha Sapi } \\
\text { Potong }\end{array}$ & $\begin{array}{c}\text { Usaha Padi } \\
\text { Sawah }\end{array}$ & \multirow{2}{*}{ Total } \\
\hline 1 & Total Biaya Produksi & 112.870 .000 & 38.215 .000 & 153.851 .000 \\
2 & Penerimaan & 122.650 .000 & 50.960 .000 & $178.960,000$ \\
3 & Keuntungan & 9.780 .000 & 12.745 .000 & 25.109 .000 \\
& R/C & $\mathbf{1 , 0 9}$ & $\mathbf{1 , 3 3}$ & $\mathbf{1 , 1 6}$ \\
\hline
\end{tabular}

Sumber : Data Primer diolah 2014

Tabel 4. Nilai Efisiensi Usaha Penggemukkan Sapi Potong dan Budidaya Padi Sawah Terpadu

\begin{tabular}{|c|c|c|c|c|c|c|}
\hline \multirow{2}{*}{ No } & \multirow{2}{*}{$\begin{array}{c}\text { Komponen } \\
\text { Biaya }\end{array}$} & \multicolumn{4}{|c|}{ Usahatani Terpadu } & \multirow{2}{*}{ Total } \\
\hline & & $\begin{array}{l}\text { Usaha Sapi } \\
\text { Potong }\end{array}$ & $\begin{array}{c}\text { Usaha } \\
\text { Padi } \\
\text { Sawah } \\
\end{array}$ & $\begin{array}{c}\text { Usaha } \\
\text { Jerami } \\
\text { Padi }\end{array}$ & $\begin{array}{l}\text { Jumlah } \\
\text { Pupuk } \\
\text { Organik }\end{array}$ & \\
\hline 1 & $\begin{array}{l}\text { Total Biaya } \\
\text { Produksi (Rp) } \\
\text { Penerimaan }\end{array}$ & 170.119 .500 & 36.780 .750 & 67.662 .000 & 80.514 .672 & 355.076 .922 \\
\hline 2 & $\begin{array}{l}\text { (Rp) } \\
\text { Keuntungan }\end{array}$ & 192.000 .000 & 50.960 .000 & 144.000 .000 & 142.091 .280 & 529.051 .280 \\
\hline 3 & (Rp) & 21.880 .500 & 14.179 .250 & 76.338 .000 & 61.576 .608 & 173.974 .358 \\
\hline & $\mathrm{R} / \mathrm{C}$ & 1,13 & 1,39 & 2,13 & 1,76 & 1,49 \\
\hline
\end{tabular}

Sumber : Data Primer diolah 2014

organik dan usaha pengadaan pakan jerami padi. Nilai R/C usahatani terpadu sebesar 1,49 menunjukkan terjadi peningkatan $29,30 \%$ dibandingkan nilai $\mathrm{R} / \mathrm{C}$ usaha tunggal yang sebesar 1,16.

Menurut Kusnadi dan Prawiradiputra (1993), integrasi ternak dan tanaman dapat meningkatkan keuntungan antara
14,9-129,4\%. Penelitian ini menunjukkan bahwa peningkatan keuntungan dapat mencapai lebih dari $100 \%$. Hal ini dikarenakan penerimaan tidak hanya bersumber dari penjualan ternak, pupuk organik dan GKP. Akan tetapi, penerimaan juga bersumber dari penjualan jerami yang nilai R/C-nya bahkan mencapai 2,13. Persentasi keuntungan tersebut 
lebih baik dari persentase keuntungan usaha integrasi sesuai penelitian Basuni, dkk (2008) di Cianjur. Penelitian tersebut menunjukkan bahwa sistem integrasi padi dan sapi potong dapat meningkatkan keuntungan petani sebesar $69,45 \%$.

\section{KESIMPULAN DAN SARAN}

Berdasarkan hasil dapat disimpulkan, bahwa: usahatani terpadu sapi potong dan padi sawah di Kelompok Tani "Keong Mas" efisien dan menguntungkan dibanding usahatani tunggal.

Berdasarkan hasil penelitian maka disarankan agar anggota kelompok "Keong Emas" dan masyarakat petani pada umumnya di Kabupaten Bolaang Mongondow Utara untuk memanfaatkan pupuk organik yang bersumber dari kotoran sapi.

\section{DAFTAR PUSTAKA}

Aries, K. 2008. Metode Penelitian. Bumi Aksara. Jakarta.

Basuni, Muladno, Kusmana, Suryahadi. 2008. Model Sistem Integrasi Padi-Sapi Potong di Lahan Sawah. Pusat Pengembangan dan
Pemberdayaan Pendidik dan Tenaga Kependidikan Pertanian Cianjur. IPB, Bogor. Iptek Tanaman Pangan Vol. 5 No. 1 Januari 2010.

Hamdan. 2011. Analisis Efisiensi Faktor Produksi Pada Usahatani Padi Sawah Di Bengkulu. Balai Pengkajian Teknologi Pertanian Bengkulu.

Hoddi, A.H., M.B. Rombe dan Fahrul. 2011. Analisis Pendapatan Peternakan Sapi Potong Di Kecamatan Tanete Rilau, Kabupaten Barru. Jurnal Agribisnis Vol. X (3) September 2011. Fakultas Peternakan Universitas Hasanuddin, Sulawesi Selatan.

Ismail, I.G. dan A. Djajanegara. 2004. Kerangka Dasar Pengembangan SUT Tanaman-Ternak. Proyek PPATP. Departemen Pertanian, Jakarta.

Kusnadi, U. dan B.R. Prawiradiputra. 1993. Produktivitas Ternak Domba dalam Sistem Usahatani Konservasi Lahan 
Kering di DAS Citanduy.

Risalah Lokakarya Penelitian

dan Pengembangan Sistem

Usahatani Konservasi di DAS

Citanduy, Linggarjati, 9-11

Agustus 1988. p.205-293.

Malian, A.H. 2004. Analisis

Ekonomi Usahatani dan

Kelayakan Finansial

Teknologi Pada Skala

Pengkajian. Bahan Pelatihan

"Analisis Finansial dan

Ekonomi Bagi

Pengembangan Sistem dan

Usaha Agribisnis Wilayah".

Pusat Penelitian dan

Pengembangan Sosial

Ekonomi Pertanian dan

Proyek Pengkajian

Teknologi Pertanian

Partisipatif. 28 hal.

Sariubang, M., A. Ella., A. Nurhayu., dan D. Pasambe. 2002. CLS
Sapi Potong pada Lahan

Sawah Tadah hujan. Laporan

Hasil Penelitian. Balai Penelitian Teknologi

Pertanian Sulawesi Selatan.

Sudaratmadja, I.G.A.K., N. Suyasa

dan I.G.K. Dana Arsana.

2004. Subak Dalam

Perspektif Sistem Integrasi

Padi-Ternak di Bali. Jurnal

Lokakarya Sistem dan

Kelembagaan Usahatani

Tanaman-Ternak. Badan

Litbang Pertanian, Jakarta.

Suwono, M., M.A. Yusron dan F. Kasiyadi. 2004. Penggunaan Pupuk Organik dalam Sistem Integrasi Tanaman-Ternak di Jawa Timur. Jurnal Lokakarya Sistem dan Kelembagaan Usahatani Tanaman-Ternak. Badan Litbang Pertanian, Jakarta. 